\title{
Analisis Pengaruh Penambahan Tepung Isi Rumen Sapi dalam Ransum Ayam Layer Terhadap Kualitas Putih Telur
}

\author{
Analysis of Effect of The Cattle Rument Contents Meal \\ in Layer Feed on White Egg Quality \\ Andi Suarda ${ }^{*}$, Andi Mulia ${ }^{2}$ \\ 1Jurusan Ilmu Peternakan, Fakultas Sains dan Teknologi \\ Universitas Islam Negeri Alauddin Makassar \\ 2Jurusan Ekonomi Islam, Fakultas Ekonomi dan Bisnis islam \\ Universitas Islam Negeri Alauddin Makassar \\ *Korespondensi E-mail : atta.adda@yahoo.com
}

\begin{abstract}
ABSTRAK
Penelitian ini bertujuan untuk mendapatkan gambaran sampai sejauh mana pengaruh penambahan tepung isi rumen sapi dalam ransum ayam petelur terhadap kualitas putih telur. Material yang digunakan dalam penelitian ini adalah ayam petelur fase produksi berjumlah 48 ekor, berumur Sembilan bulan, dan strain" super Harco C.P 306" yang berasal dari PT.Charoen Pokhpan Jaya Farm, Jakarta.Rancangan percobaan yang digunakan adalah Rancangan Acak Lengkap Pola Faktorial $4 \times 2$ dengan tiga kali ulangan (Steel and Torrie, 1980). Factor pertama adalah jenis ransom, yang terdiri dari R-1 yaitu ransum tanpa menggunakan tepung isi rumen sapi, R-2 adalah ransum yang mengandung 2,5 $\%$ tepung isi rumen sapi, R-3 adalah ransom yang mengandung $5 \%$ tepung isi rumen sapi, R-4 adalah ransom yang mengandung 7,5\% tepung isi rumen sapi. Sedangkan faktor kedua adalah jenis alas kandang yang terdiri dari Sekam Padi dan Slat. Peubah yang diukur dalam penelitian ini adalah ketebalan kerabang, berat kerabang. Hasil menunjukkan bahwa : 1) penggunaan tepung isi rumen sapi sampai tingkat 7,5\% didalam ransum ayam petelur tidak memperlihatkan pengaruh yang nyata terhadap berat albumen (putih telur), 2) Interaksi antara jenis ransum dan alas kandang yang digunakan tidak memperlihatkan pengaruh yang nyata terhadap berat albumen (putih telur).
\end{abstract}

Kata kunci: Albumen, Ayam Layer, Telur

\begin{abstract}
This study aims to get an idea of the extent of the effect of adding flour to the contents of cattle rumen in laying rations on the quality of egg whites. The material used in this study was 48 production hens, nine months old, and the "super Harco CP 306" strain originating from PT. Charoen Pokhpan Jaya Farm, Jakarta. The experimental design used was Factorial 4 Completely Randomized Design $4 \times 2$ with three replications (Steel and Torrie, 1980). The first factor is the type of ransom, which consists of R-1 namely ration without using flour filled with beef rumen, R-2 is a ration containing $2.5 \%$ flour filled with beef rumen, R-3 is a ransom containing 5\% flour filled with beef rumen, R-4 is a ransom containing $7.5 \%$ flour filled with beef rumen. While the second factor is the type of cage consisting of Rice Husk and Slat. The variables measured in this study
\end{abstract}


were shell thickness, shell weight. The results showed that: 1) the use of beef rumen flour up to the level of $7.5 \%$ in the ration of laying hens did not show a significant effect on the weight of albumen (egg white), 2) The interaction between the type of ration and the base of the cage used did not show a significant effect to the weight of albumen (egg white).

Keywords: Albumen, Chicken Layer, Egg

\section{PENDAHULUAN}

Telur merupakan bahan makanan yang bernilai gizi tinggi dan merupakan salah satu sumber protein yang sangat tinggibagi kehidupan manusia pada umumnya, khususnya pada anak-anak pada masa pertumbuhannya. Akan tetapi kualitas telur cepat menurun bila tidak tepat penanganannya hal ini disebabkan karena sifat telur yang mudah rusak oleh bakteri serta zat-zat makanan yang ada didalamnya pun akan dihancurkan (Fry dan Newell, 1957). Neisheim dkk. (1979) yang dilaporkan oleh Triantini dkk. (1981) bahwa isi telur segar dalam albumen memiliki beberapa sifat bakterisidal yang mencegah bakteriyang berasal dari bahan kotora (feses) masuk kedalam telur melalui pori-pori kerabang, apabila bahan kerabang tipis (Scadelman dan Cotteril. 1977). Bakteri-bakteri ini menyebabkan kerusakan isi telur secara langsung dan dapat menurunkan kualitas telur (Fry dan Newell. 1957).

Sarwono dkk. (1985) menyatakan, bahwa ada beberapa faktor yang dapat mempengaruhi berat kerabangdiantaranya: jenis hewan, umur, sifat keturunan, umur pembuahan, berat tubuh indukk, perubahan musim, dan menu makanan yang diberikan pada ayam. Selanjutnya Anggorodi (1979) mengemukakan, bahwa factor-faktor lain yang tidak ada hubungannya dengan makanan dapat menimbulkan problema-problema kualitas telur antara lain; suhu lingkungan sekeliling yang tinggi, penyakit, genetic serta umur ayam itu sendiri. Demikian pula dengan yang dikembangkan oleh Zakaria (1980) bahwa kelainankelainan yang menyebabkan kualitas-kualitas telur menurun adalah disebabkan oleh terlalu banyaknya kadar kalsium didalam ransum sehingga dapat menimbulkan penimbunan kalsium pada kulit telur.

Amrullah (1984) menyatakan, bahwa untuk mencegah tipisnya kerabang adalah memperbaiki makanan yaitu ransum harus cukup mengandung kalsium, sebab pada umumnya kulit telur terdiri dari kalsium karbonat. Selanjutnya Wahyu (1985) menyatakan bahwa kberadaan kalsium dan fosfor dalam ransom sangat mempengaruhi berat dan ketebalan kerabang telur. Mirosson (1969) menyatakan, bahwa kandungan zat-zat makanan dari tepung ikan sangatlah baik sehingga dianjurkan pemakaiannya untuk makanan ternak 
ayam. Selain komposisi za makanan, tepung ikan kaya akan mineral Ca dan P yang sangat berguna dalam pembentukan tulang dan kulit telur. Simon (1974) yang dikutip oleh zakaria (1980) mengatakan bahwa banyak faktor yang mempengaruhi kekuatan dari kulit telur antara lain : pengaruh lapisan tipis (membran) bagian dalam dari kulit telur itu sendiri, mamile dan columna, serta distribusi dari para matrix.

Albumen adalah bagian dari pada isi telur yang terletak diantara kulit telur dan kuning telur, dan menempati posisi terbesar pada isi telur yaitu sekitar $60 \%$ dari berat telur (Romanof, 1963). Lebih lanjut dikatakan, bahwa air adalah bagian terbesar dari albumen dan kadarnya kurang dari luar dan dalam sehingga kekentalannya rata-rata antara 11-13\%. Stadelman dan Cotteril (1977) menyatakan bahwa persentasi albumen sekitar 56-61\%. Selanjunya Ensminer (1971), menyatakan bahwa albumen mempunyai persentase sekitar $58 \%$, sedang total kekentalannya tergantung pada strain dan umur ayam. Demikia pula yang dilaporkan Jansen dkk.(1978) yang dikutip oleh Zakaria (1980) menyatakan, bahwa perubahan perubahan makanan ayam dengan mengurangi jumlah makanan yang diberikan kepada ayam yang sedang berproduksi, tidak berpengaruh terhadap kualitas bagian dalam dari pada telur dan diasumsikan bahwa mengurangi jumlah kebutuhan makanan akan menaikkan kadar albumen didalam telur.

Rumusan masalah dalam penelitian ini, yaitu bagaimana pengaruh penambahan tepung isi rumen sapi dalam ransum ayam layer terhadap kualitas putih telur. Tujuan dari penelitian ini yaitu untuk mendapatkan gambaran sampai sejauh mana pengaruh penambahan tepung isi rumen sapi dalam ransum ayam petelur terhadap kualitas putih telur. Disamping itu, untuk mengurangi bahaya pencemaran lingkungan karena limbah isi rumen, selain itu untuk mengatasi kesulitan penanganan limbah tersebut sebagai salah satu hasil buangan rumah potong hewan. Hasil penelitian ini diharapkan dapat dijadikan sebagai sumber informasi kepada berbagai pihak terkait pengaruh penambahan tepung isi rumen sapi dalam ransum ayam layer terhadap kualitas putih telur.

\section{METODE PENELITIAN}

\section{Jenis dan Lokasi Penelitian}

Jenis penelitian ini adalah penelitian kuantitatif yang di kandang penelitian ayam layer, Rumah Potong Hewan Makassar, dan Laboratorium Makanan Ternak Fakultas Peternakan, Universitas Hasanuddin. 


\section{Sumber dan Metode Pengumpulan Data}

Material yang digunakan dalam penelitian ini adalah ayam petelur fase produksi berjumlah 48 ekor, berumur Sembilan bulan, dan strain "super Harco C.P 306" yang berasal dari PT.Charoen Pokhpan Jaya Farm, Jakarta. Ayam tersebut dipelihara dalam 24 kandang masing-masing berukuran $1 \times 0,5 \times 1 \mathrm{~m}$ yang terbuat dari belahan bambu yang lebarnya $2 \mathrm{~cm}$ tersusun dengan jarak 1,5-2 cm. alas kandang yang digunakan terdiri dari sekam padi dan Slat.

Penempatan ayam didalam kandang dilakukan secara acak, dimana setiap kandang diisi dua ekor ayam yang dilengkapi masing-masing satu buah tempat makan dan minum. Tempat makan dan minum diletakkan sedemikian rupa didalam kandang, sehingga setiap ayam mendapat kesempatan yang sama untuk makan dan minum. Pemberian makanan dilakukan secara ad-libitum.

Isi rumen sapi diperoleh dari Rumah Potong Hewan, Kota Makassar dengan pengambilan sempel dilakukan pada, pukul 05.00 pagi. Kemudian sempel tersebut dikeringkan dibawah matahari kurang lebih 10 hari, lalu digiling dilabolatorium Makanan Ternak Fakultas Peternakan, Universitas Hasanuddin, Makassar. Periode pendahuluan berlangsung satu minggu dan pengambilan data selama delapan minggu untuk penilaian kualitas telur dilakukan pemecaahan telur setiap hari. Pencegahan terhadap penyakit ND (New Castle Disease) dilakukan dengan pemberian vaksinasi Sotasec yang disuntikkan melalui intra muskuler dan pencegahan terhadap penyakit CRD (Chroniced Respiratory Disease) diberikan obat Suanovil yang dilarutkan dalam air minum.

Rancangan percobaan yang digunakan adalah Rancangan Acak Lengkap Pola Faktorial $4 \times 2$ dengan tiga kali ulangan (Steel and Torrie, 1980). Factor pertama adalah jenis ransom, yang terdiri dari R-1 yaitu ransum tanpa menggunakan tepung isi rumen sapi, R-2 adalah ransum yang mengandung 2,5\% tepung isi rumen sapi, R-3 adalah ransom yang mengandung $5 \%$ tepung isi rumen sapi, R-4 adalah ransum yang mengandung 7,5\% tepung isi rumen sapi. Keempat macam ransum tersebut disusun berdasarkan rekomendasi NRC (1977) secara isonetrogenous ( $\pm 16 \%$ protein). Sedangkan faktor kedua adalah jenis alas kandang yang terdiri dari sekam padi dan slat. Peubah yang diukur dalam penelitian ini adalah berat albumen (putih telur),. Berat albumen (putih telur) didapatkan dengan menimbang langsung. 


\section{HASIL DAN PEMBAHASAN}

Komposisi bahan makanan dan susunan zat-zat dari masing-masing ransum terlihat pada Tabel 1 dan Tabel 2. Analisis sidik ragam menunjukkan, bahwa jenis ransum tidak memperlihatkan pengaruh yang nyata terhadap berat putih telur (albumen) ayam per butir selama penelitian. Hal ini kemungkinan disebabkan karena baik konsumsi air minum maupun nilai gizi ransom terutama protein pada masing-masing ransom relative seimbang.

Tabel 1. Komposisi Bahan Makanan dari Masing-masing Ransum yang Dipergunakan dalam Penelitian*)

\begin{tabular}{ccccc}
\hline \multirow{2}{*}{ Bahan Makanan } & \multicolumn{4}{c}{ Jenis Ransum } \\
\cline { 2 - 5 } & R-1 & R-2 & R-3 & R-4 \\
\hline Jagung & 55,0 & 54,0 & 53,0 & 52,0 \\
Dedak Padi & 12,0 & 10,5 & 9,0 & 7,5 \\
Tepung Ikan & 10,0 & 10,0 & 10,0 & 10,0 \\
Bungkil Kedele & 4,0 & 4,0 & 4,0 & 4,0 \\
Bungkil Kelapa & 15,0 & 15,0 & 15,0 & 15,0 \\
Tepung Kerang & 3,5 & 3,5 & 3,5 & 3,5 \\
Rhodiamix & 0,5 & 0,5 & 0,5 & 0,5 \\
Tepung Isi Rumen Sapi & - & 2,5 & 5,0 & 7,5 \\
Total & 100 & 100 & 100 & 100 \\
Protein Kasar & 16,175 & 16,178 & 16,181 & 16,184 \\
\hline Keter
\end{tabular}

Keterangan : *) Disusun Berdasarkan Rekomendasi Wahyu (1978).

Hasil penelitian ini sesuai dengan yang dilaporkan oleh Jansen dkk., (1978) yang dikutip leh Zakaria (1980) menyatakan, bahwa perubahan makanan ayam dengan mengurangi jumlah makanan yang diberikan pada ayam yang sedang berproduksi tidak berpengaruh terhadap kualitas baigan dari pada telur dan diasumsikan bahwa mengurangi jumlah kebutuhan makanan akan menaikkan jumlah kadar putih telur (albumen) didalam telur, hal ini kemungkinan disebabkan oleh karena jumlah makanan tidak mencukupi dari kebutuhan yang semestinya maka terpaksa minum air lebih banyak dan mengakibatkan cairan putih telur (albumen) akan meningkat dan disamping itu pula adanya serat kasar yang relative tinggi dalam ransum ayam. 
Tabel 2. Komposisi Zat-zat dari Masing-masing Ransum Penelitian, ${ }^{*}$

\begin{tabular}{ccccc}
\hline \multirow{2}{*}{ Zat-zat Makanan } & \multicolumn{4}{c}{ Perlakuan } \\
& R-1 & R-2 & R-3 & R-4 \\
\hline Kadar Air & 11,26 & 11,36 & 11,55 & 11,53 \\
Protein Kasar & 16,21 & 16,19 & 16,22 & 16,18 \\
Serat Kasar & 5,17 & 5,36 & 5,62 & 5,67 \\
Lemak & 5,35 & 5,26 & 5,17 & 5,09 \\
B E T N & 55,75 & 55,36 & 54,77 & 54,71 \\
A b u & 6,26 & 6,47 & 6,67 & 6,82 \\
Kalsium & 1,91 & 1,91 & 1,90 & 1,90 \\
Fosfor & 0,69 & 0,67 & 0,64 & 0,62 \\
\hline
\end{tabular}

Tabel 3. Komposisi Makanan Tepung Isi Rumen Sapi *)

\begin{tabular}{cc}
\hline Zat-Zat Makanan & Persen \\
\hline Air & 11,15 \\
Protein Kasar & 10,82 \\
Lemak & 3,35 \\
Serat Kasar & 24,18 \\
B E T N & 33,50 \\
A b u & 17,00 \\
Kalsium & 1,22 \\
Fosfor & 0,55 \\
\hline
\end{tabular}

Keterangan :*) Analisis Labolatorium Makanan Ternak Fakultas Peternakan, Universitas Hasanuddin, Makassar

Tabel 4. Komposisi Rhodiamix yang digunakan dalam Ransum Penelitian.

\section{Tiap $1 \mathrm{~kg}$ Rhodiamix mengandung}

\begin{tabular}{cc}
\hline Vitamin A & $120.0000 \mathrm{IU}$ \\
Vitamin D 3 & $400.000 \mathrm{IU}$ \\
Vitamin E & $500 \mathrm{mg}$ \\
Vitamin B 2 & $800 \mathrm{mg}$ \\
Vitamin B 12 & $1 \mathrm{mg}$ \\
Vitamin B 1 & $100 \mathrm{mg}$ \\
Vitamin B 6 & $20 \mathrm{mg}$ \\
Vitamin K 3 & $400 \mathrm{mg}$ \\
Vitamin C & $500 \mathrm{mg}$ \\
Calsium d-pantothenate & $1.000 \mathrm{mg}$ \\
Choline chloride & $15.000 \mathrm{mg}$ \\
DI-Methionine & $5.000 \mathrm{mg}$ \\
Nicotinic Acid & $1.600 \mathrm{mg}$ \\
Calsium & $2.000 \mathrm{mg}$ \\
Iron & $3.600 \mathrm{mg}$ \\
Copper & $1.200 \mathrm{mg}$
\end{tabular}




\begin{tabular}{cc}
\hline \multicolumn{2}{c}{ Tiap 1 kg Rhodiamix mengandung } \\
\hline Magnesium & $7.000 \mathrm{mg}$ \\
Mariganese & $9.600 \mathrm{mg}$ \\
Zinc & $3.600 \mathrm{mg}$ \\
Cobalt & $60 \mathrm{mg}$ \\
Iodine & $120 \mathrm{mg}$ \\
Antioxidant & $\mathrm{Qs}$ \\
\hline
\end{tabular}

*) Produksi; PT. Rhone Polenc Indonesia Farma.

Tabel 5. Rrata-rata berat putih telur ayam per butir selama penelitian.

\begin{tabular}{|c|c|c|c|c|c|c|}
\hline \multirow{2}{*}{$\begin{array}{c}\text { Jenis } \\
\text { Alas } \\
\text { Kandang }\end{array}$} & \multicolumn{6}{|c|}{ Jenis Ransum } \\
\hline & Ulangan & R-1 & R-2 & $\mathrm{R}-3$ & $\mathrm{R}-4$ & Jumlah \\
\hline \multirow{2}{*}{ Sekam } & 1 & 36,78 & 33,73 & 37,05 & 35,49 & \\
\hline & 2 & 35,17 & 37,06 & 35,77 & 36,31 & \\
\hline Padi & 3 & 36,04 & 37,37 & 35,43 & 36,40 & \\
\hline \multicolumn{2}{|c|}{ Jumlah } & 107,99 & 108,16 & 108,25 & 108,20 & 432,6 \\
\hline \multicolumn{2}{|c|}{ Rata-rata } & 36,00 & 36,05 & 36,08 & 36,07 & \\
\hline \multirow{3}{*}{ Slat } & 1 & 35,04 & 35,72 & 38,30 & 38,47 & \\
\hline & 2 & 36,15 & 38,62 & 35,53 & 35,85 & \\
\hline & 3 & 38,29 & 35,18 & 35,85 & 35,25 & \\
\hline \multicolumn{2}{|c|}{ Jumlah } & 109,48 & 109,52 & 109,68 & 109,57 & 438,25 \\
\hline \multicolumn{2}{|c|}{ Rata-rata } & 36,49 & 36,51 & 36,56 & 36,52 & \\
\hline \multicolumn{2}{|c|}{ Total } & 217,47 & 217,68 & 217,93 & 217,77 & 870,85 \\
\hline
\end{tabular}

Hal yang dapat mengakibatkan ayam mengkonsumsi air minum cukup banyak untuk membantu proses pencernaan kasar yang dapat mengakibatkan berkurangnya kekentalan putih telur (albumen) yang pada gilirannya mempengaruhi kualitas putih telur (albumen) menurun.

Jenis alas kandang yang dipergunakan tidak memperlihatkan pengaruh yang nyata terhadap berat putih telur ayam per butir selama penelitan. Hal ini disebabkan karena temperature dalam kandang normal, sehingga ayam mengkonumsi air minum merata yang dapat mengakibatkan berat putih telur relative sama. Hasil penelitian ini sejalan yang dikemukakan oleh Rahardjo (1981) menyatakan, bahwa ayam dalam keadaan normal mengkonsumsi air minum 2-2,5 kali lebih banyak dari jmlah mkanannya, dan bila suhu meningkat ayam akan meningkatkan konsumsi air minumnya. Lebih lanjut dikatakan, bahwa suhu ideal bagi ayam 13-21 ${ }^{\circ} \mathrm{C}$. 
Demikian pula interaksi antara jenis ransom dan jenis alas kandang yang digunakan tidak memperlihatkan pengauh yang nyata terhadap berat putih telur (albumen) ayam per butir selama penelitian.

\section{KESIMPULAN}

Berdasarkan hasil analisis sidik ragam dan pembahasan maka dapat disimpulkan bahwa : Penggunaan tepung isi rumen sapi sampai tingkat 7,5\% didalam ransum ayam petelur tidak memperlihatkan pengaruh yang nyata terhadap albumen (putih telur). Interaksi antara jenis ransum dan alas kandang yang digunakan tidak memperlihatkan pengaruh yang nyata terhadap albumen (putih telur). Penelitian mengenai penggunaan tepung isi rumen sapi dalam ransum khususnya ayam fase produksi sangat kurang, maka perlu dilakukan penelitian lebih lanjut, tentang penggunaan tepung isi rumen tersebut pada persentase lebih tinggi.

\section{DAFTAR PUSTAKA}

Abbas, M. H. 1982. Pengaruh Beberapa ingkat Phospor dan Protein Ransum terhadap Performance Ayam Broiler pada Kandang alas Kawat dan Litter. Tesis. Fakultas Pasca Sarjana Institut Pertanian Bogor. Bogor.

Amrullah, I. K. 1984. Kerabang telur penentu keuntungan. Majalah Ayam dan Telur. Jakarta. No.1:22-23

Anggorodi, R. 1979. Ilmu Makanan Ternak Umum. P.T. Gramedia. Jakarta.

Anggorodi, R.1985. Kemajuan Mutakhir Dalam Ilmu Nutrisi Ternak Unggas. Universitas Indonesia Press. Jakarta.

Anonymous. 1978. Laporan Survey Masalah Penanganan Telur Direktorat Jendral Peternakan. Fakultas Pertanian IPB. Bogor.

Hariana. 1987. Pengaruh Pemanfaatan Daun Ubi Kayu dalam Ransum Terhadap Kualitas Telur. Tasis Fakultas Peternakan, Universitas Hasanuddin Ujung Pandang.

York. Sarwono, B., Murtidjo, B.A., dan Daryanto, A. 1985. Telur Pengawetan dan Manfaatnya. P.T. Penebar Swadaya Anggota IKAPI. Jakarta.

Soerman, 1981. Hubungan Antara Produksi Telur Jumlah Ayam dan Luas Lantai Kandang Pada Usaha Peternakan Ayam Petelur yang menggunakan Sistem Litter di Kota Madya Ujung Pandang. Skripsi. Fakultas ILMU-Ilmu Pertanian. Univesitas Hasanuddin. Ujung Pandang.

Steel, R.G. and Torrie, J.H. 1980. Principles and Procedures of Statistics. Mc Graw Hill Book Company Inc. New York.

Santoso, U. 2001. Effect of Sauropus androgynus Extract on Organ Weight, Toxicity and Number of Salmonella sp and Escherichia coli of Broilers Meat. B I P P, 7 (2): 162-169.

Santoso, U. 2005. Pengaruh Pemberian Ekstrak Daun Katuk Dalam Ransum Terhadap Produksi, Kadar Nitrogen dan Forsor, dan Jumlah Koloni Mikrobia pada Feses Ayam Petelur. Jurnal Pengembangan Peternakan Tropis, 30 (4): 237-241. 
Santoso, U and Sartini. 2001. Reduction of Fat Accumulation in Broiler Chickens by Sauropus Androgynus (Katuk) Leaf Meal Supplementation. Asian-Aust. J. Anim. Sci. 14: 346350.

Santoso, U., Suharyanto and Handayani, E 2001. Effects of Sauropus Androgynus (Katuk) Leaf Extract on Growth, Fat Accumulation and Fecal Microorganismse in Broiler Chickens. J I T V, 6: 220-226.

Santoso, U., Suteky, T., Heryanto dan Sunarti. 2002. Pengaruh Cara Pemberian Ekstrak Daun Katuk (Sauropus Androgynus) Terhadap Penampilan Dan Kualitas Karkas Ayam Pedaging. J I T V, 7: 143-148.

Togatorop, M.H. 1980. Pengaruh Pemeliharaan di Atas Lantai Kawat V.S. Lantai Litter Dengan Pemberian Ransum yang Mengandung Berbagai Tingkat Energi Terhadap Performancs Ayam Broiler. Tesis Sekolah Pasca Sarjana, Institut Pertanian Bogor, Bogor. 